Review

\title{
Municipal Solid Waste Management Policies, Practices, and Challenges in Ethiopia: A Systematic Review
}

\author{
Lemesa Hirpe (D) and Chunho Yeom *(D) \\ International School of Urban Sciences, University of Seoul, Seoul 02504, Korea; yobsanlemessa@gmail.com \\ * Correspondence: chunhoy7@uos.ac.kr; Tel.: +82-2-6490-5154
}

check for

updates

Citation: Hirpe, L.; Yeom, C.

Municipal Solid Waste Management

Policies, Practices, and Challenges in

Ethiopia: A Systematic Review.

Sustainability 2021, 13, 11241. https:/ /

doi.org/10.3390/su132011241

Academic Editors:

María del Consuelo Hernández Berriel,

Amaya Lobo García de Cortázar

and Ana Lorena Esteban García

Received: 17 August 2021

Accepted: 6 October 2021

Published: 12 October 2021

Publisher's Note: MDPI stays neutral with regard to jurisdictional claims in published maps and institutional affiliations.

Copyright: (c) 2021 by the authors. Licensee MDPI, Basel, Switzerland. This article is an open access article distributed under the terms and conditions of the Creative Commons Attribution (CC BY) license (https:// creativecommons.org/licenses/by/ $4.0 /)$.

\begin{abstract}
Municipal Solid Waste Management (MSWM) affects several spheres, including environmental, social, and economic activities. In Ethiopia, massive waste generation and unbalanced management have worsened the issue. Hence, this systematic review investigates the Ethiopian MSWM policy and legal frameworks, practices, and challenges. The Scopus and Web of Science databases and Google Scholar were used to search published and unpublished studies from 2005 to 2021, and a website search was used to find studies from 1995 to 2021. The search was restricted to the English language, and the last search was conducted on 25 June 2021. The study was extracted from the characteristics of the developed study. A risk of bias assessment was conducted for the included studies using the AMSTAR 2. Among the 1135 identified records, 72 studies were found to be eligible. This systematic review identified numerous legal frameworks that enhance the implementation of MSWM in Ethiopia, which is mainly focused on waste collection, transportation, and disposal. Lack of policy enforcement, weak capacity, public awareness, and minimal cooperation among stakeholders were the main challenges. MSWM problems in Ethiopia have seen an increase in recent decades and are affecting daily life. Therefore, these findings may help to improve MSWM in Ethiopia.
\end{abstract}

Keywords: municipal solid waste management; legal framework; systematic review; policy enforcement

\section{Introduction}

Municipal solid waste management (MSWM) is a multidisciplinary activity that includes administrative activities and solid waste management practices such as the control of waste generation, storage, collection, transfer and transport, processing, and disposal of solid waste [1]. Its overall goal is to reduce and eliminate the adverse impacts of waste on human health and the environment and to support economic development and quality of life [2]. Hence, effective MSWM plays a significant role in improving the quality of the environment, human health, and socioeconomic activities of local communities. However, according to the United Nations Environment Programme (UNEP) [3], MSWM is a major environmental problem and a public health concern. The negative environmental, social, and economic impacts of solid waste are more severe in developing than in the developed countries [4]. Similarly, this municipal solid waste problem is worse in urban areas, where enormous industrial and other activities widely occur. Simultaneously, various MSWM activities in developing countries are performed by public sectors, and these sectors alone are unable to deliver solid waste management services effectively, with the limited enforcement of MSWM policies [5]. Thus, the illegal open burning and dumping of solid waste are common practices in many developing countries [6].

Additionally, the rapid increase in population coupled with the expansion of the industry is producing large volumes of waste, whose management demands greater infrastructure, institutional setup, and community participation [7]. This massive generation of waste coupled with unbalanced waste management is a major challenge faced by developing countries, particularly the sub-Saharan African countries. The sub-Saharan African 
countries are characterized by the least gross domestic product, and a large portion of their populations live below the poverty line. However, according to the recent World bank study [4], the economic development of the majority of sub-Saharan African countries is growing at a fast rate, as well as the population growth and urbanization in sub-Saharan African countries are increasing from time to time. Moreover, Ethiopia is one of the fastestgrowing countries in sub-Saharan African countries and the second country in terms of population among all African countries. As a result, the municipal solid waste management problems, such as an increasing generation rate of solid waste and open burning and dumping in sub-Saharan African countries, are found at an alarming rate [5]. Therefore, Ethiopia is selected as the case study of this systematic review because the authors believed that Ethiopia could represent the sub-Saharan African countries and even other developing countries.

On the other hand, the Ethiopian government has previously adopted MSWM policies and legal frameworks to reduce and eradicate the environmental and human health impacts caused by improper waste management practices [8]. In Ethiopia, MSWM is a major issue owing to its fast-growing economy, expansion of urbanization, and industrial development in its major cities [9]. Hence, the MSWM problem in Ethiopia is a critical issue affecting the environment, human health, and economic activities [10], and it is especially affecting the quality of life of the local communities. In addition, some studies have indicated that the low performance of MSWM in Ethiopian cities and the environmental and public health problems due to the high rate of uncollected solid waste is continued at high speed in major cities in the country [9]. As a result, the MSWM problem is getting worse and is one of the serious cross-cutting issues of Ethiopia. Even though the responsibility for MSWM in Ethiopia is given to municipalities through a decentralization policy, most are unable to solve their waste problems [11]. Thus, MSWM in Ethiopia has mainly targeted waste collection from source and its transportation to disposal sites. This is mainly due to inadequate institutional capacity, finances, knowledge, and awareness, lack of solid waste baseline data, minimal cooperation among stakeholders, weak political commitment and prioritization, and a lack of effective planning and implementation [12-14].

Therefore, this systematic review tries to provide useful information which will help to develop the municipal solid waste management strategy in Ethiopia, based on the existing studies on the policy and legal frameworks, practices, and challenges in Ethiopia. As a result, it aims at answering the following key questions:

1. What are the available policy and legal frameworks of MSWM in Ethiopia?

2. What are the current municipal solid waste management practices in Ethiopia?

3. What are the main challenges of municipal solid waste management in Ethiopia?

\section{Materials and Methods}

A systematic literature review was conducted on existing literature from various included studies. Maphosa [15] states that a systematic literature review helps identify, evaluate, analyze, and interpret relevant research literature based on a specific research question. It also maps published studies on specific topics [16]. This method is followed by the Preferred Reporting Items for Systematic Review and Meta-Analysis (PRISMA) 2020 statement - the updated guidelines for reporting systematic reviews that replaced PRISMA 2009 [17]. The PRISMA 2020 checklists were used for this systematic review of municipal solid waste management policies, practices, and challenges in Ethiopia.

Study eligibility criteria: Published and unpublished studies from January 2005 to July 2021 were included but were restricted to those in the English language. Government policies, legislation, and regulations related to municipal solid waste management in Ethiopia from the government website (Environment, Forest, and Climate Change Commission of Ethiopia), written in English, were also included. The solid waste management policy and legal frameworks formulated from 1995 to July 2021 are included because these are long-term tools, and the government still uses them. 
Information Sources and Search Strategy: Based on the eligibility criteria of the review, electronic searches on Scopus and Web of Science databases and Google Scholar were conducted from 1 January 2021 to 25 June 2021. The search strategies for each search engine included titles and abstracts. Each objective of this review was also searched for (i.e., MSWM policy and legal frameworks, practices, and challenges in Ethiopia), along with policies and legal frameworks regarding the Ethiopian Environment, Forest, and Climate Change Commission. The online search strategy was restricted to the English language, and the timeframe included published and unpublished studies dating back to 2005 and policy and legal framework to 1995.

Study Selection: Following the initial screening for duplication, the reviewers independently reviewed the studies by titles and abstracts and discussed the final records. The entire contents of the selected papers were then examined for the eligibility criteria by a single reviewer. The final decision was made by discussing the independently screened studies by titles, abstracts, and eligibility criteria. Figure 1 shows the 72 studies qualified for this systematic review.

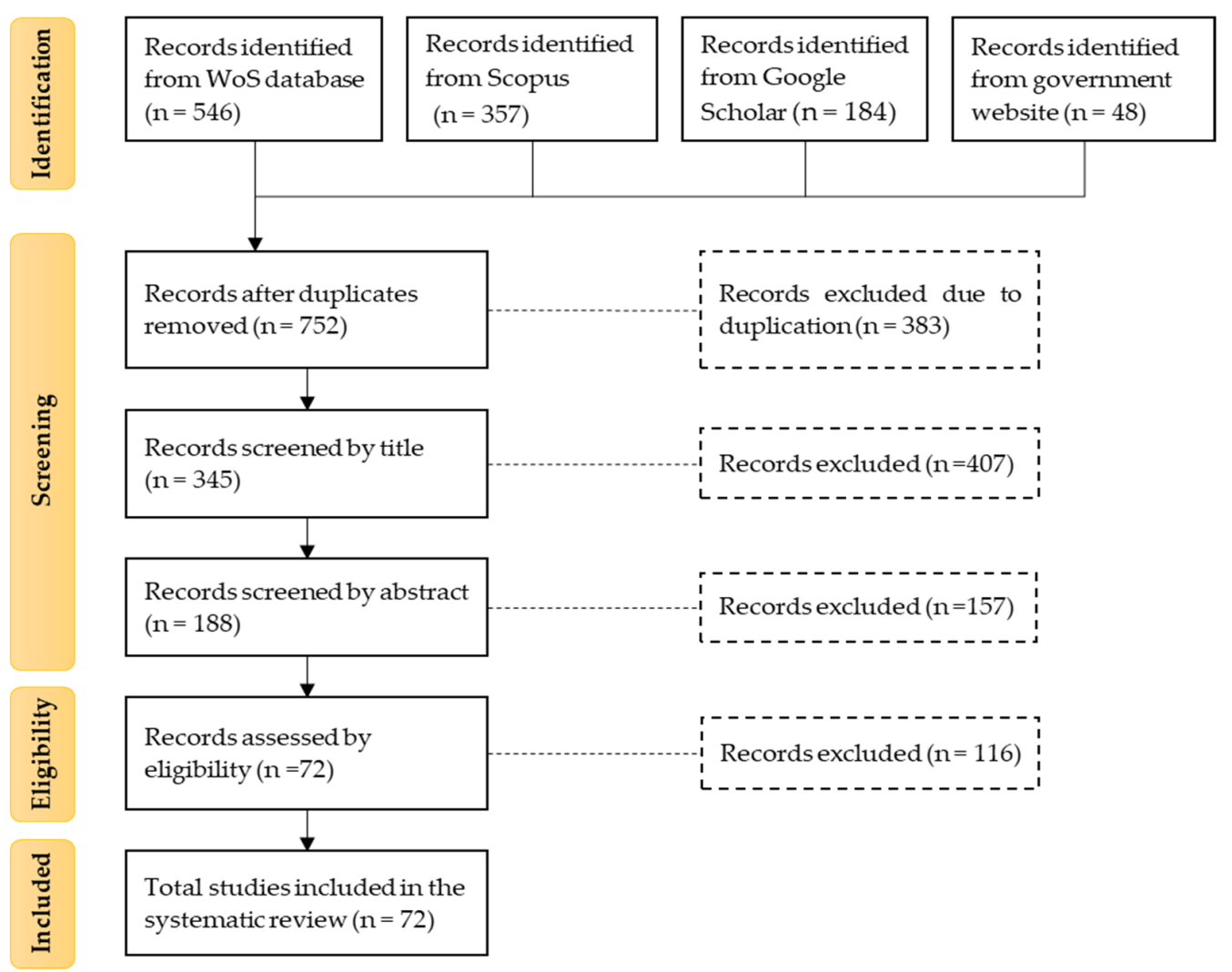

Figure 1. PRISMA flow diagram for the summary of study selection.

Data Collection Process: Standardized data extraction was developed to extract the study characteristics, such as study year, sample size, content details, and the plot was tested on five randomly selected articles. Data extraction was then performed for all articles, and the proceedings were checked for the final outcome.

Study Risk of Bias Assessment: The risk of bias was assessed using the measurement tool to assess systematic reviews (AMSTAR 2), during which the contents of the included articles were focused upon. Then, the detailed results of this systematic review are discussed in the next section.

\section{Results}

The municipal solid waste management policy and legal frameworks, practices, and major challenges that hinder such practices in Ethiopia are discussed below. 


\subsection{Policy and Legal Frameworks for Municipal Solid Waste Management in Ethiopia}

Ethiopia has several policies and legal frameworks that support the enforcement of the MSWM system in the country [8]. Moreover, Ethiopia has ratified a few international waste management conventions. Some of these municipal solid waste management policies and legal frameworks formulated by the Federal Democratic Republic of Ethiopia (FDRE) and the international waste conventions are discussed below.

The 1995 FDRE Constitution: The 1995 Constitution of the Federal Democratic Republic of Ethiopia is the cornerstone of all policies in the country, including environmental policies, and has highlighted some environmental issues in the country. Article 44 addresses environmental rights in Sub-article 1: "all persons have the right to a clean and healthy environment", while Article 92 addresses the government's environmental objectives in Sub-article 1: "the government shall endeavor to ensure that all Ethiopians live in a clean and healthy environment", and Sub-article 4 indicates that "government and citizens shall have the duty to protect the environment" [18]. These provide all Ethiopian people with the right to live in a clean and healthy environment and the responsibility imposed on the government and citizens to protect the environment.

The 1997 Ethiopian Environmental Policy: The Environmental Policy of Ethiopia was adopted in 1997, and its overall goal is to improve and enhance the health and quality of life for all Ethiopians and promote sustainable social and economic development through sound management of environmental resources [19]. This policy addressed the concept of waste management in the next three sub-articles. Article 3(7) Human Settlement, Urban Environment, and Environmental Health indicated waste collection services, recycling of solid waste, safe disposal, and the essence of scientific studies to identify suitable sanitary landfills. In addition, Article 3(8) Hazardous Materials and Pollution from Industrial Waste explained safe sanitary landfill sites, formulation of guidelines and regulations to control waste from different sectors, as well as waste minimization and recycling, handling, and storage of hazardous and dangerous materials, and monitoring of waste management implementation. Moreover, Article 3(9) Atmospheric Pollution and Climate Change addressed the essence of appropriate measures on the contributors of atmospheric pollution and climate change, such as methane gas, which can be emitted from unmanaged landfills.

Public Health Protection Proclamation No. 200/2000: Article 12 of this proclamation states that "any person shall collect waste at an especially designated place and in a manner, which does not affect the health of the society" [20]. It prohibits the disposal of solid, liquid, or any other waste in a manner that affects the environment and public health. In addition, this proclamation indicates that any waste generated from hospitals should be handled through disposal procedures that meet public health and environmental standards.

Environmental Impact Assessment Proclamation No. 299/2002: The EIA proclamation enforces project proponents to undertake an EIA for projects considered to have significant environmental and social impacts [21]. Waste disposal facilities, such as waste incineration and landfill sites, require an EIA before implementation. Therefore, EIA is very significant in the municipal solid waste management system.

Environmental Pollution Control Proclamation 300/2002: This proclamation covered the management of hazardous and non-hazardous wastes, specifically Article 5 of the proclamation. Sub-article 1 of Article 5 states, "all urban administrations shall ensure the collection, transportation, recycling, treatment or safe disposal of municipal waste through the institution of an integrated municipal waste management system" [22]. The proclamation also addressed the importance of cooperation between municipal solid waste management and relevant environmental authorities to monitor and evaluate the municipal solid waste management systems and to ensure the effectiveness of their implementation.

Ratified International Waste Conventions: Ethiopia has ratified two international conventions: The Rotterdam Convention via proclamation No. 278/2002 and the Basel Convention via proclamation No. 357/2003, which have an essential role in the improvement of the solid waste management systems in the country. The Rotterdam Convention promotes shared responsibility and cooperation among parties in the international trade 
of hazardous chemicals to protect the environment and human health [23]. Concurrently, the Basel Convention is an international treaty on the control of the transboundary movement of hazardous waste and its disposal. The main goal of the latter convention is to protect human health and the environment from the adverse effects of hazardous and other kinds of waste and to control its movement between countries [24]. Thus, the ratification of these conventions by the Ethiopian government has a significant role in the development of municipal solid waste management systems in the country and at the international level.

Solid Waste Management Proclamation No. 513/2007: This proclamation is the first national policy on solid waste management in Ethiopia and its main objective is to enhance the capacity to prevent adverse impacts of solid waste at all social levels while creating economically and socially beneficial assets from solid waste [25]. This policy mainly covers the general obligations of urban administration, solid waste management planning, the inter-regional movement of solid waste, the management of household solid waste, waste collection and storage, transportation, recycling, incineration, disposal, and auditing of solid waste disposal sites. It also addresses the significance of community participation in its mission. The solid waste management action plans designed by and implemented at local urban administrative levels help ensure community participation. The main drawback of this policy is its lack of supporting guidelines, which is highly important to implement solid waste management laws and proclamations. Additionally, sustainable solid waste management strategies, such as waste prevention and reduction, solid waste segregation at source, and waste collection fee systems have not got attention.

Electrical and Electronic Waste Management and Disposal Regulation No. 425/2018: It was the first national regulation on electrical and electronic waste management and disposal in Ethiopia. It addresses the hierarchy of waste management to minimize the environmental and social impacts of electrical and electronic waste by reducing waste generation, refurbishing, reuse, recycling, and disposal of such waste [26]. It also implements the extended producer responsibility principle for electrical and electronic waste management, the first of its kind in Ethiopia.

Hazardous Waste Management and Disposal Control Proclamation No. 1090/2018: This proclamation aims to create a system for environmentally sound management and disposal of hazardous waste and to prevent damage to human or animal health, the environment, biodiversity, and/or property due to the mismanagement of such waste [27]. It is the primary national hazardous waste management and disposal control proclamation, which identifies the categories of waste to control, chemical constituents, and the characteristics of hazardous waste. The proclamation contains 24 basic articles covering clean production principles, the responsibilities of hazardous waste generators and hazardous-waste labeling, storage, reuse, treatment, and recycling, as well as the handling and disposal of hazardous waste. It also addressed transboundary movement, illegal transactions, and the inter-state movement of hazardous waste.

\subsection{Municipal Solid Waste Management Practices in Ethiopia}

Over the last few decades, several studies have been conducted on MSWM in Ethiopian towns and cities. Since 2001, most municipalities in Ethiopia have become aware of the negative consequences of poor solid waste management that affects the environment, human health, and municipal services [10]. This has led to MSWM practices in many Ethiopian towns and cities. However, some studies have shown that MSWM practices vary among all urban centers in Ethiopia [28], depending on the awareness of the municipalities and their capacity for solid waste management. Similarly, a study conducted in Malaysia showed that MSWM practices through the basic hierarchical components varied greatly across different towns and cities, even though MSWM systems are designed to protect the environment and improve conditions in all cities [29]. Additionally, a study conducted in Zimbabwe [30] stated that MSWM practices could differ for residential and industrial producers, urban and rural areas, and developed and developing nations; in particular, many developing countries are characterized by poor solid waste management due to 
unbalanced systems. In sub-Saharan African countries, such as Ethiopia, the solid waste management systems are varied and weak, particularly the status of waste prevention, reduction, reuse, recycling, and energy recovery is very low.

Current Ethiopian MSWM is mainly focused on the collection, transport, and disposal of solid waste; the implementation of the functional elements is, however, still weak [12]. Similarly, a study conducted in Bangladesh [31], Mozambique [32], and Nigeria [33] indicated that, similar to most developing countries, waste is collected from generation sources and transferred to ultimate disposal sites. This indicates that sustainable solid waste management strategies, such as prevention, reduction, reuse, recycling, and final disposal in many Ethiopian towns and cities, require attention from the government because the solid waste handling, recycling, and performance of disposal systems remain very poor in Ethiopia $[13,34]$. In short, the implementation of the basic functional elements of a solid waste management system in Ethiopia is weak [12]. Hence, the whole MSWM system in Ethiopia should be improved and replaced by sustainable MSWM; however, open burning and dumping, waste collection, and final disposal require critical attention from the government. Figure 2 shows the flow of MSWM practices in many urban areas of Ethiopia.

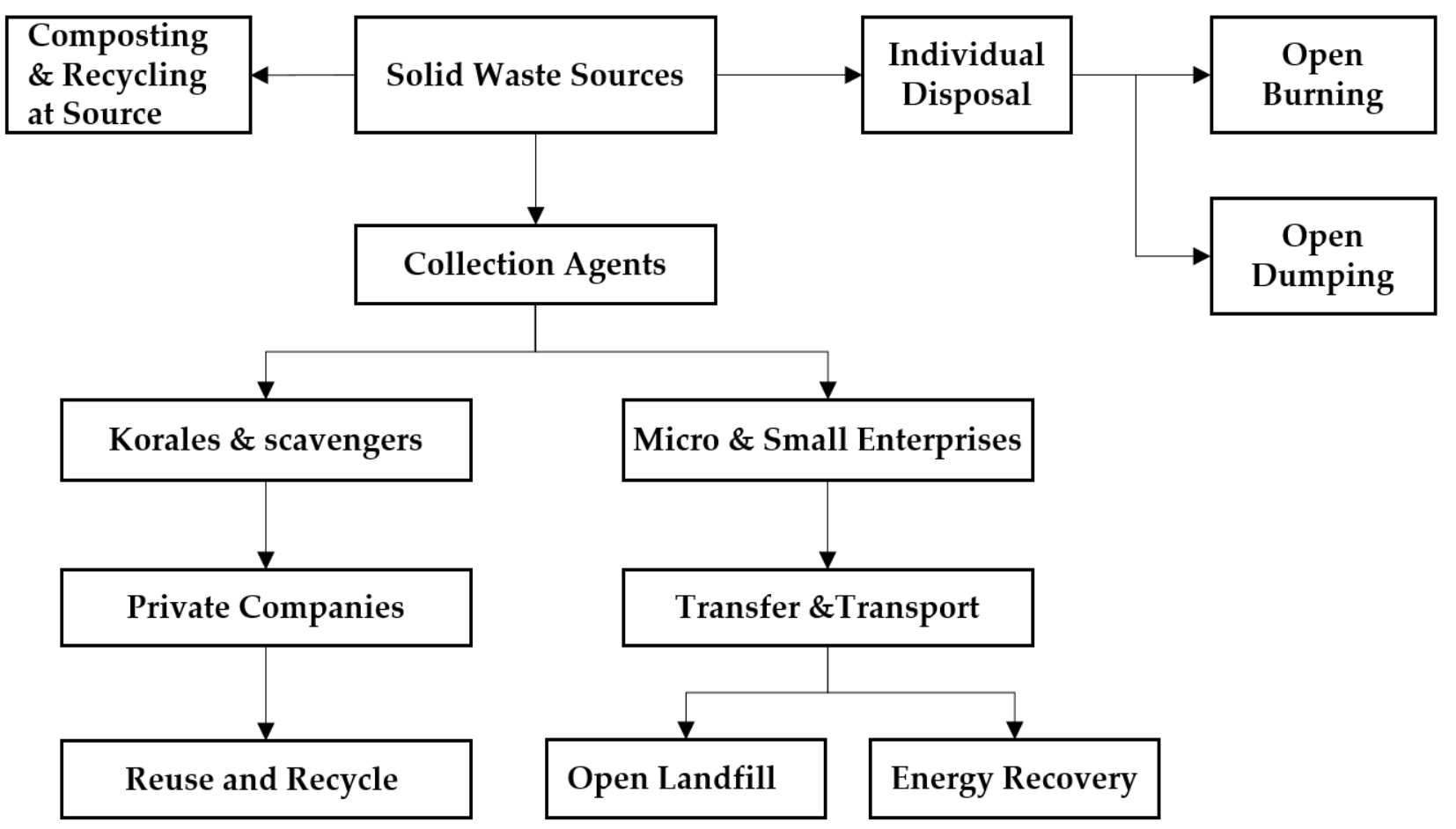

Figure 2. The flow of municipal solid waste management practices in Ethiopia.

\subsubsection{Waste Generation}

Waste generation is calculated as the total amount of waste from different sources at a specific time and place. Sub-Saharan African countries generated approximately 174 million tons of solid waste in 2016 at a rate of 0.46 kilograms per capita per day, which is expected to triple by 2050 [4]. However, the amount of solid waste generated may be directly affected by the wealth of society. By contrast, the World Bank [4] estimated the municipal solid waste generation rate in Ethiopia to be 6 million tons/year in 2015 and is predicted to rise to 10 million tons/year by 2030 and 18 million tons/year by 2050 . A previous study [35] projected a total municipal solid waste generation rate in Ethiopia by 2025 at about $0.65 \mathrm{~kg}$ /capita/day (19,690 tons/day, or about 7.18 million tons/year). Moreover, studies conducted in Ethiopian towns and cities showed that the average rate of solid waste generated by households ranged from 0.23 to $2.03 \mathrm{~kg} /$ capita/day [36]. A study conducted in 10 cities of the Amhara, Oromia, Tigray, and South Nations and Nationalities regions of Ethiopia indicated that the overall solid waste generation rate was 
$0.32 \mathrm{~kg} /$ capita/day [37]. This shows the high contribution of households to solid waste generation in Ethiopia, akin to many other countries. Table 1 shows the details of municipal solid waste generation (MSWG) rates in different towns and cities in Ethiopia.

Table 1. Municipal solid waste generation (MSWG) rates in different towns and cities of Ethiopia.

\begin{tabular}{ccc}
\hline Town/City & MSWG (kg/Capita/Day) & Source \\
\hline Dilla & 0.475 & {$[38]$} \\
Chiro & 0.30 & {$[7]$} \\
Burayu & 0.29 & {$[39]$} \\
Robe & 0.26 & {$[40]$} \\
Addis Ababa & 0.45 & {$[41]$} \\
Mekelle & 0.27 & {$[42]$} \\
Bahir Dar & 0.45 & {$[43]$} \\
Wolaita Sodo & 0.47 & {$[44]$} \\
Jimma & 0.34 & {$[45]$} \\
Laga Tafo & 0.41 & {$[46]$} \\
Debre Birhan & 0.25 & {$[47]$} \\
Jigjiga & 0.49 & {$[48]$} \\
Hawassa & 0.43 & {$[49]$} \\
Dassie & 0.45 & {$[50]$} \\
\hline
\end{tabular}

According to Table 1, the municipal solid waste generation in different cities and towns of Ethiopia shows an average municipal solid waste generation rate ranging from 0.25 to $0.49 \mathrm{~kg} /$ capita/day. Furthermore, residents, commercials, institutions, industries, hotels, and street sweepings are the major sources of solid waste generation in urban areas of Ethiopia. However, the amount of waste generated was different from each source. For example, among the total municipal solid waste generation of Addis Ababa, households account for $70 \%$, commercial institutions $9 \%$, industries $6 \%$, hotels $3 \%$, hospitals $1 \%$, street sweepings $10 \%$, and other sources accounted for $1 \%$ [51]. This shows that the majority of municipal solid waste generation comes from households. In Ethiopia, there are no effective strategies, such as a volume-based waste fee system that helps minimize waste generation at sources. However, according to Kim [52], the volume-based waste fee system was introduced in South Korea in 1995 to reduce waste generation and encourage waste recycling, and it has successfully improved municipal solid waste generation and collection practices.

\subsubsection{Waste Composition}

Africa, in recent times, has seen not only an increase in solid waste but also a change in waste composition [5]. As economic development and industrialization increase, the percentage of organic waste decreases, particularly in developed countries. However, the waste generated by sub-Saharan African countries consists of a high percentage of organic waste due to the preparation of fresh food and the use of less packaging on goods that are sold in the markets; hence, the waste composition in these cities is characterized by food and green waste at $43 \%$, plastics at $8.6 \%$, paper and cardboard $10 \%$, metal $5 \%$, glass $3 \%$, wood less than $1 \%$, and other waste at 30\% [4]. Similarly, the systematic literature review of existing studies from various towns and cities revealed that the majority of the solid waste composition in Ethiopia is organic. Figure 3 shows a high share of organic waste among the municipal solid waste composition in Ethiopia. 


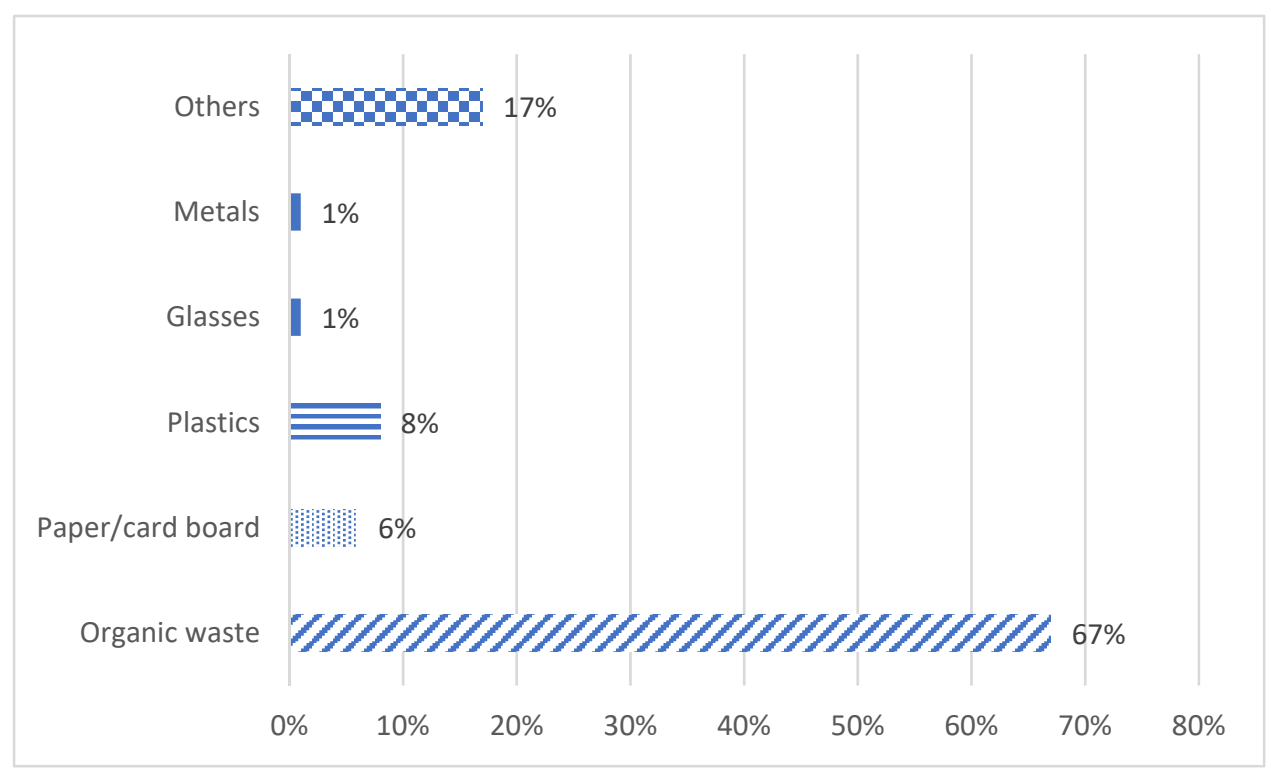

Figure 3. MSW composition in Ethiopia [12].

\subsubsection{Waste Collection}

Solid waste collection is one of the main components of municipal solid waste management [51]. In urban areas of Ethiopia, formal solid waste collection is mostly conducted by micro and small enterprises that collect waste door-to-door and transport the waste to facilities and disposal points [39]. Additionally, informal groups, called street boys and scavengers, collect solid waste in many urban areas of Ethiopia [53]. They also collect recyclable solid waste from households, temporary waste containers, and visiting open dumpsites. A previous study assessing solid waste management in 28 Ethiopian cities and towns found that $88 \%$ of households use sacks to collect solid waste [36]. This indicates that the majority of households store solid waste in containers that do not meet municipal standards. Moreover, low-income countries such as Ethiopia still face major challenges in ensuring solid waste collection services, eliminating uncontrolled solid waste disposal, open burning, and moving towards sustainable management for all solid waste [54]. This may be even more difficult in the future in major cities of low-income countries with to the likelihood of population increase over the next few years, which also leads to prioritizing waste issues in these cities.

Moreover, the percentage of solid waste collection in three Ethiopian cities, Addis Ababa, Hawassa, and Bahir Dar, was 70\% [4], 80\% [55], and 57\% [56], respectively. This indicates that $30 \%, 20 \%$, and $43 \%$ of solid waste was left uncollected in these respective cities in 2018. Simultaneously, according to Henry et al. [57], approximately $30-60 \%$ of the waste generated is left uncollected in urban areas of developing countries. Additionally, the solid waste collection coverage in Sousse, Tunisia, and Lagos, Nigeria is higher than $90 \%$, whereas the solid waste collection coverage in Accra (Ghana), Kampala (Uganda), and Moshi (Tanzania) is $80 \%, 65.2 \%$, and $61 \%$, respectively [5]. Even though it is difficult to decide only depending on the waste collection rate, the authors expected that more than $90 \%$ of municipal solid waste collection coverage may decrease the current environmental problems, public health issues, and economic burdens due to uncollected solid waste problems in Ethiopia. However, in developing countries, such as Ethiopia, an estimated $20-50 \%$ of the solid waste generated in many urban areas is left uncollected at its source [58]. This uncollected waste can be stored on the surface of the land, and it is carried by runoff water, particularly during the rainy seasons. These lead to the accumulation of solid waste in water bodies and the drainage system, which directly causes the blockage of drains and damage to the environment and communities. 
Additionally, a recent study in Addis Ababa showed that uncollected solid waste is disposed of the spaces, ditches, and rivers [9]. In Ethiopia, solid waste collection coverage is much higher in capital cities than in small towns, where a collection system is sometimes non-existent. Uncollected waste can cause environmental, such as groundwater, land, and air pollution, and also public health problems, such as respiratory, growth, and skin problems, and water diarrhea problems. Although solid waste management has become a major environmental and public health concern in urban areas of Ethiopia, only about $2 \%$ of the population has such services [59]. Therefore, the implementation of effective solid waste collection policies and practices is required in urban areas of Ethiopia, and this literature review indicated that the country's solid waste collection system was weak in various cities.

\subsubsection{Waste Prevention, Reduction, Reuse, Recycling, and Energy from Waste}

Solid waste generation prevention and reduction, as well as reuse, recycling, and wasteto-energy conversion strategies, are not well implemented in developing countries such as Ethiopia. According to the UNEP [54], approximately $70-80 \%$ of municipal solid waste generated in Africa is recyclable, but only $4 \%$ of it is currently recycled by the private sector. Moreover, the African Union Commission mainly aimed to recycle at least $50 \%$ of urban waste in African cities by 2023 [60]. Thus, recycling initiatives by private companies are already underway for waste such as plastics, paper, glass, metals, and organic waste in some Ethiopian cities, such as Addis Ababa; however, it is important to scale up such implementations by introducing new recycling companies and strengthening end-product markets. Concurrently, the urban solid waste recycling activities in Ethiopia were not adequate; for example, only about 5\% of the solid waste generated in Addis Ababa is recycled [41]. This shows that Ethiopia requires several years to achieve the goal of the African Union Commission to recycle its urban waste. Additionally, the first stage of the solid waste recycling process includes separating the waste into different categories [61]. Solid waste separation at the source has a crucial advantage in encouraging reuse and recycling strategies in urban areas. The informal private sector has promoted the reuse and recycling of solid waste; for example, individuals are known as "korales" who buy reusable bottles, jars, and recyclable materials from households and sell them to shopkeepers and merchants in Addis Ababa [62]. They also sometimes collect reusable and recyclable solid waste from dumpsites and sell it to private companies.

Furthermore, according to the USEPA Best Practices for Solid Waste Management [2], recovering energy from waste on a large scale by using an advanced incineration plant is a commonly practiced waste management system in developed countries but requires highly sophisticated technology, skilled labor, and is at a high cost. Waste-to-energy plants also have an environmental effect unless systematically managed. In 2018, Ethiopia constructed the Repi waste-to-energy plant in Addis Ababa at the Koshe dumpsite, which is expected to incinerate up to 1400 tons of waste per day (roughly $80 \%$ of Addis Ababa's waste) and serve $30 \%$ of the city's household electricity needs [5], generating approximately $50 \mathrm{MW}$ of electric power. However, the plant is not fully operational owing to a lack of raw materials and financial resources. In general, sustainable MSWM strategies, such as waste prevention, reduction, reuse, recycling, and waste-to-energy practices, are weak in Ethiopia. Similarly, Wilson et al. [63] stated that sustainable municipal solid waste strategy systems were weak in low-income countries due to financial challenges.

\subsubsection{Waste Transfer and Transport}

Waste transfer stations are intermediate places where solid waste is deposited and stored until they are transported to the processing and final disposal sites [41]. Hence, transfer and transport activities for municipal solid waste include those related to transferring the waste from the collection areas to temporary storage places and transporting it to the processing facilities and final disposal sites. A previous study conducted on MSWM in Addis Ababa states that the municipality is responsible for the transportation of municipal 
solid waste to waste-to-energy plants and final disposal sites, and the role of micro and small enterprises is limited in the transportation of solid waste [51]. However, the towns and cities of developing countries have insufficient transfer and transport facilities for solid waste. Similarly, in many Ethiopian towns and cities, the collected waste is stored on the roadside, in the open, and exposed to rain and sun, which creates a bad odor and attracts pests [64]. This directly affects the quality of the environment and public health around the solid waste transfer stations.

\subsubsection{Waste Disposal}

Waste disposal is the final step in municipal solid waste management to protect the environment and people from solid waste impacts [65]. The quality of the waste disposal facility may depend on the availability of technology, skilled workers, and the financial resources of each country. Open dumping (unplanned dumping of waste without consideration for environmental protection and public health) is the most common method of waste disposal in Africa, with open burning coming close as another regularly used mechanism to eliminate waste [5]. Thus, the unplanned and unmanaged solid waste disposal practices severely harm the environment and public health around disposal areas and also affects the lives of future generations by increasing greenhouse gases that contribute to climate change [3]. According to the OpenWASH report [61], the two main waste disposal methods in Ethiopia are landfills (including waste burial pits and communal open dumping) and thermal processing, which includes the burning and incineration of solid waste. However, there are no standardized waste disposal sites for most towns and cities in Ethiopia. Moreover, Mohammed [66] stated that most urban areas in Ethiopia use open dumping for waste disposal, which pollutes the surface and groundwater, soil, and natural environment as a whole.

In developing countries, less attention has been paid to waste minimization strategies that result in the sending of wastes to dumpsites for final disposal [67]. Openly burning solid waste is another common practice, while incineration is mostly used to treat health care waste in Ethiopia. According to the African Development Bank Report in 2019, the final disposal systems of solid waste in Ethiopian cities are not environmentally friendly because over $50 \%$ of the urban population practice open burning [12]. This indicates that solid waste management systems in Ethiopia have several constraints that affect their implementation. Some of these challenges are discussed in the next section.

\subsection{Challenges of Municipal Solid Waste Management in Ethiopia}

Municipal solid waste management in Ethiopia is a major environmental problem affecting the daily lives of people, particularly in urban areas. This systematic literature review of the existing literature on MSWM in Ethiopia identified the main challenges in the area. Solid waste management is a cross-cutting issue that impacts many social and environmental aspects (including the economy) of the country [54]. It has a strong relationship with global challenges such as environmental pollution, climate change, public health, and sustainable production and consumption. According to the study by Guerrero et al. [68], increasing waste generation, budget issues, lack of cross-sectorial linkages, and waste handling systems were the challenges faced in MSWM in several developing countries. Similarly, the EFCCC State and Outlook of the Environment [8] revealed that the main challenges of MSWM in Ethiopia stem from unplanned historical patterns in several towns and cities, little public awareness of solid waste management, inappropriate waste disposal methods affecting the environment and human health, limited access to waste collection services, limited awareness about and application of formal waste recycling, and limited public and private investment in solid waste management. Additionally, the lack of effective enforcement of policies and legislation, fewer financial resources, inadequate infrastructure, a lack of skilled workers, and few managerial commitments are the other major challenges faced by MSWM in Ethiopian towns and cities [34]. Moreover, at the community level, the country lacks proper awareness and education regarding waste 
prevention, reduction, reuse, and recycling, and there is little information on composting and energy recovery from solid waste [13].

However, despite some legal frameworks in place, several cities in Ethiopia continue to face municipal solid waste management challenges [69]. These challenges may range from generating a large amount of waste to an inappropriate waste disposal system. According to a recent study conducted by Gelan [9] in Addis Ababa, the challenges include a lesser emphasis on MSWM by the government, the scarcity of land to perform different activities concerning solid waste management, particularly for temporary storage and disposal sites, financial scarcity, the lack of solid waste collection and transportation infrastructure, and the lack of skilled human resources. In addition, Teshome [12] stated that the MSWM systems in Ethiopia are irregular in collection and transportation, inadequate at waste prevention and collection coverage, inefficient from technical aspects, weak at the enforcement level of solid waste management policy and legal frameworks, and sometimes the presence of political interference in solid waste management. Additionally, other challenges in solid waste management for Ethiopian urban areas include weak cooperation among stakeholders (particularly government and private companies), a lack of regular monitoring and evaluation, a lack of effective planning and implementation, and weak public participation [70]. Figure 4 shows the details of municipal solid waste management challenges in Ethiopia, particularly challenges regarding policy/legal frameworks, institutional, technical, financial, social, and political aspects.

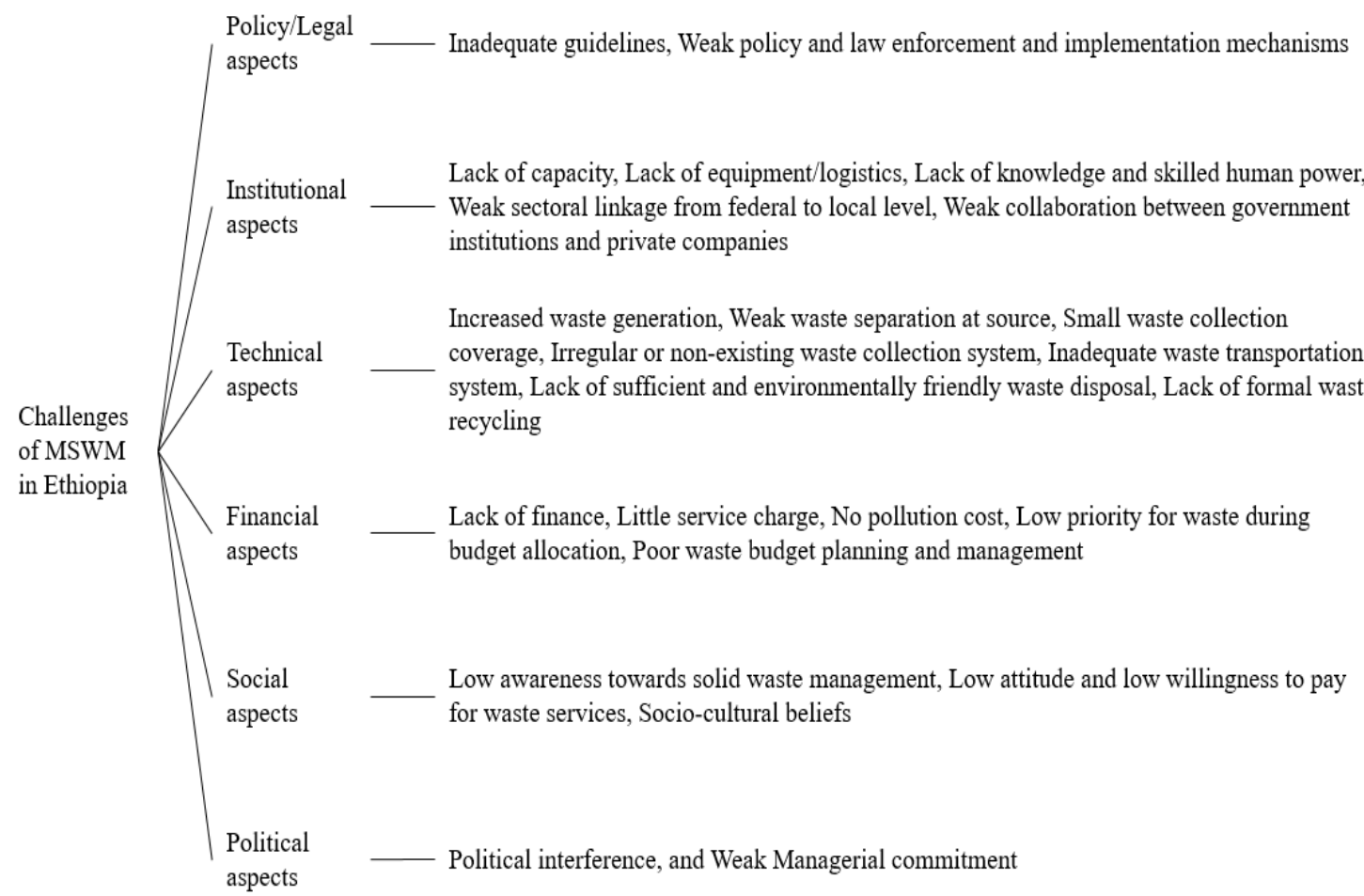

Figure 4. Summary of the major challenges of municipal solid waste management in Ethiopia $[8,9,12,13,34,46,68,70]$.

\section{Discussion}

This systematic literature review was conducted on published and unpublished studies from 2005 to 2021 and the working policy and legal frameworks from 1995 to 2021 to analyze the policies, practices, and challenges of MSWM in Ethiopia. The review is based on a total of 72 studies that met the eligibility criteria, searched through Scopus and Google Scholar databases and the government website. The results presented in this systematic review are supported by other published studies on MSWM, particularly in Ethiopia. Haylamicheal and Desalegne [71] found that various MSWM policies and legislations support solid waste management practices in Ethiopia. These findings are consistent with 
our results that policy and legal frameworks are the cornerstones for implementing and enforcing MSWM at all levels. Similarly, the OpenWASH report [61] stated that solid waste collection, transport, and final disposal were the main focus of such practices in Ethiopia. These findings are also consistent with our results that solid waste collection is covered by micro and small enterprises and local scavengers, and open burning and open dumping were the main municipal solid waste disposal systems in Ethiopia.

Additionally, Teshome [12] found a weak solid waste management system in Ethiopia due to inadequate guidelines, weak enforcement, inadequate waste collection coverage, a lack of finances, and a lack of formal solid waste recycling systems, except for some practices by private companies. Our results also support these findings that the main challenges of MSWM in Ethiopia were concerned with policy and legal aspects (with minimal attention given to solid waste prevention, lack of technical guidelines), institutional aspects (weak cooperation among sectors and other stakeholders, weak human and material capacity), technical aspects of solid waste management (lack of solid waste separation at source, limited solid waste collection and coverage), social aspects (low awareness and attitudes of the community), financial aspects (lack of finance and low priority given for solid waste management), and political aspects (low priority for solid waste management due to political interference). On the other hand, titles and abstracts were independently screened for this systematic review. However, a recent study conducted by Gartlehner et al. [72] showed that single titles and abstract screening skipped up to $13 \%$ of the relevant studies. Additionally, this review is limited to articles published in English. However, the data extraction and bias assessment were conducted to ensure that these limitations do not change the overall results and conclusions of the review.

Furthermore, depending on this systematic review of municipal solid waste management policies, practices, and challenges in Ethiopia, this systematic review's contributions and implications are addressed. First, this systematic review addressed the current progress of municipal solid waste management in Ethiopia. It will develop understanding and fill the gaps in the existing literature by providing significant evidence of Ethiopia's municipal solid waste management policies and practices at the national level. Second, this review allows policymakers, stakeholders, and researchers to acquire the summarized current state of municipal solid waste management policies, practices, and challenges in Ethiopia. This review is unique in addressing all functional elements of municipal solid waste management practices at the country level. Third, this review helps the policymakers and other stakeholders to modify policies and plans according to the findings of this review and suggestions forwarded to improve the municipal solid waste management in Ethiopia. Fourth, in addition to the significance of the findings of this paper to the study area, the evidence from this paper has a high contribution for municipal solid waste management of other developing countries on an extensive scale, particularly in sub-Saharan African countries, in the area where similar problems might be happening. Fifth, it may serve as a reference for academic purposes and widen the scope for future studies on municipal solid waste management areas. Sixth, it identifies the needed research area, especially the research gaps on sustainable municipal solid waste management strategies, such as waste prevention, reduction, reuse, recycling, and energy recovery from waste.

In the future, the municipal solid waste management systems in Ethiopia should focus on sustainable solid waste management strategies, such as waste generation prevention, reduction, reuse, recycling, composting, and waste-to-energy on a large scale and solve the current challenges in solid waste management practices in the country. Therefore, the contributions of this systematic review and future studies implications may lead to sustainable municipal solid waste management in Ethiopia, which enhances the environmental, social, and economic sustainability.

\section{Conclusions}

In this systematic review, an overview of the municipal solid waste management policies and legal frameworks, practices, and challenges in Ethiopia were presented de- 
pending on the main qualitative questions of this review. Then, based on the findings of this systematic literature review, the following conclusions were drawn. Ethiopia has adopted environmental policy, municipal solid waste management proclamations, and other related regulations; however, its implementation and enforcement are not well practiced in the country. The implementation of MSWM policies and legislations in Ethiopia requires integrated enforcement to achieve sustainable solid waste management. Specific technical guideline frameworks (separation at the source, waste prevention, reduction, reuse, and recycling; converting waste to energy) were not available to bring sustainable MSWM at all levels of government.

MSWM in Ethiopia is associated with various environmental, social, and economic issues that require critical attention from the government. In recent times, the volume of waste generation in many Ethiopian cities has seen an increase due to the migration from rural to urban areas and industrialization. The increase in solid waste volume and an unbalanced waste management system have led to a degradation in environmental quality and an increased harm to public health. Additionally, this review found that the practices of MSWM in Ethiopia were different in each city and region. However, solid waste collection in many capital cities was found to be more efficient, whereas solid waste management in many small towns was inefficient and sometimes non-existent. The role of micro and small enterprises was significant in the municipal solid waste collection system of Ethiopia, particularly that of door-to-door solid waste collection. Moreover, sustainable solid waste management practices, such as the prevention and reduction of waste generation, reuse, recycling, composting, and energy recovery from waste were found to be inefficient because MSWM in Ethiopia is mainly focused on the collection, transport, and disposal. Additionally, open burning and dumping are the most commonly practiced solid waste disposal systems in many towns and cities in Ethiopia.

In short, the implementation of MSWM practices in Ethiopia presents numerous challenges, including the lack of policy and legal framework enforcement, financial constraints, a lack of skilled human resources, infrastructure constraints, and the low public awareness of solid waste management. Additionally, minimal cooperation among MSWM stakeholders, weak planning and implementation of solid waste management, especially the low priority given for solid waste management in many cities of Ethiopia, have contributed to the issue. According to these review results, the various challenges exacerbate MSWM problems in Ethiopia, and this directly affects the environment and public health. Hence, institutional capacity building and effective enforcement of legal frameworks are crucial in improving the MSWM system in Ethiopia. Additionally, the authors suggested some technical regulations, such as the volume-based waste fee system and waste charge on the producers of hard-to-recycle products to reduce solid waste generation. Moreover, it is essential to sort the solid waste at the households' and community bin level into food waste, plastics, paper and cardboard, glass and metals, and non-recyclable waste categories, which helps to reduce the amount of solid waste and to encourage reusing, recycling, and composting strategies.

Furthermore, increasing the awareness of the community on the strategies that support the reduction of solid waste, such as waste separation at source, buying products that use less packaging, buying in large quantities to reduce packaging, using reusable rather than disposable materials, using their own shopping bags, such as those made of cloth and recyclable materials, minimizing and composting food waste, and, if possible, feeding animals. Therefore, future research should address the integrated sustainable solid waste management that aims to protect and enhance public health, the environment, and material and energy recovery through the promotion of environmental quality, sustainable consumption, and production to transform solid waste management opportunities into a circular economy practice in Ethiopia. 
Author Contributions: Conceptualization, L.H.; methodology, L.H.; validation, L.H. and C.Y.; formal analysis, L.H.; investigation, L.H.; resources, L.H.; data curation, L.H.; writing-original draft preparation, L.H.; writing-review and editing, C.Y.; visualization, C.Y.; supervision, C.Y.; project administration, C.Y.; funding acquisition, C.Y. All authors have read and agreed to the published version of the manuscript.

Funding: This work was supported by the 2021 Research Fund of the University of Seoul for Chunho Yeom. This work was also supported by the Ministry of Education of the Republic of Korea and the National Research Foundation of Korea (NRF-2020S1A5C2A01092978).

Institutional Review Board Statement: Not applicable.

Informed Consent Statement: Not applicable.

Data Availability Statement: Not applicable.

Conflicts of Interest: The authors declare no conflict of interest.

\section{References}

1. Rada, E.C.; Ragazzi, M.; Fedrizzi, P. Web-GIS oriented systems viability for municipal solid waste selective collection optimization in developed and transient economies. Waste Manag. 2013, 33, 785-792. [CrossRef]

2. USEPA Best Practices for Solid Waste Management: A Guide for Decision-Makers in Developing Countries. 2020. Available online: https: / / www.iges.or.jp/en/pub/best-practices-solid-waste-management-guide-decision-makers-developing-countries / en (accessed on 2 June 2021).

3. UNEP. Africa Waste Management Summary for Decision-Makers. 2018. Available online: https://wedocs.unep.org/handle/20.5 $00.11822 / 25515$ (accessed on 12 July 2021).

4. World Bank What a Waste 2.0: A Global Snapshot of Solid Waste Management to 2050. 2018. Available online: https:// openknowledge.worldbank.org/handle/10986/30317 (accessed on 12 July 2021).

5. Sandra, V.N.; Weghmann, V. Municipal Solid Waste Management Services in Africa. 2019. Available online: https://www.worldpsi.org/sites/default/files/documents/research/waste_management_in_africa_2018_final_dc_without_highlights_2019.pdf (accessed on 4 May 2021).

6. Weldeyohanis, Y.H.; Aneseyee, A.B.; Sodango, T.H. Evaluation of current solid waste disposal site based on socio-economic and geospatial data: A case study of Wolkite town, Ethiopia. GeoJournal 2020. Available online: https://link.springer.com/article/10 .1007/s10708-020-10268-3\#citeas (accessed on 12 July 2021). [CrossRef]

7. Umer, N.; Shimelis, G.; Ahmed, M.; Sema, T. Solid Waste Generation Rate and Management Practices in the Case of Chiro Town, West Hararghe Zone, Ethiopia. Am. J. Environ. Prot. 2019, 8, 87. [CrossRef]

8. EFCCC State and Outlook of the Environment; Addis Ababa, Ethiopia. 2017. Available online: https://wedocs.unep.org/rest/ bitstreams /11770/retrieve (accessed on 12 July 2021).

9. Gelan, E. Municipal Solid Waste Management Practices for Achieving Green Architecture Concepts in Addis Ababa, Ethiopia. Technologies 2021, 9, 48. [CrossRef]

10. Hailemariam, M.; Ajeme, A. Solid waste management in Adama, Ethiopia: Aspects and challenges. Integr. Dev. Water Supply Sanit. 2014, 8, 670-676.

11. Nebiyou, M. Decentralization and Municipal Service Delivery: The Case of Solid Waste Management in Debre Markos Town, Amhara National Regional State, Ethiopia; Addis Ababa University: Addis Ababa, Ethiopia, 2020.

12. Teshome, F.B. Municipal solid waste management in Ethiopia; the gaps and ways for improvement. J. Mater. Cycles Waste Manag. 2020, 23, 18-31. [CrossRef]

13. Edward, S. Ethiopian Environment Review No.1.2010: Forum For Environment; Addis Ababa, Ethiopia. 2010. Available online: http://www.phe-ethiopia.org/pdf/Ethiopian_Environment_Review.pdf (accessed on 7 July 2021).

14. Mengistie, B.; Baraki, N. Community based assessment on household management of waste and hygiene practices in Kersa Woreda, Eastern Ethiopia. Ethiop. J. Heal. Dev. 2010, 24, 103-109. [CrossRef]

15. Maphosa, V.; Maphosa, M. E-waste management in Sub-Saharan Africa: A systematic literature review. Cogent Bus. Manag. 2020, 7, 1-19. [CrossRef]

16. de Almeida Biolchini, J.C.; Mian, P.G.; Natali, A.C.C.; Conte, T.U.; Travassos, G.H. Scientific research ontology to support systematic review in software engineering. Adv. Eng. Informat. 2007, 21, 133-151. [CrossRef]

17. Page, M.J.; McKenzie, J.E.; Bossuyt, P.M.; Boutron, I.; Hoffmann, T.C.; Mulrow, C.D.; Shamseer, L.; Tetzlaff, J.M.; Akl, E.A.; Brennan, S.E.; et al. The PRISMA 2020 statement: An updated guideline for reporting systematic reviews. BMJ $2021,1,372$. [CrossRef]

18. FDRE Constitution of the Federal Democratic Republic of Ethiopia; Addis Ababa, Ethiopia. 1995. Available online: https: / / www.refworld.org/docid/3ae6b5a84.html (accessed on 12 May 2021).

19. FDRE Environmental Policy of Ethiopia; Addis Ababa, Ethiopia. 1997. Available online: https://www.informea.org/sites/ default/files/imported-documents/UNEP-CHW-NATLEG-NOTIF-Ethiopia01-LAW.English.pdf (accessed on 12 April 2021). 
20. FDRE Public Health Proclamation No. 200/2000; Addis Ababa, Ethiopia. 2000. Available online: https://www.ilo.org/dyn/ natlex/natlex4.detail?p_isn=85162\&p_lang=en (accessed on 15 April 2021).

21. FDRE Environmental Impact Assessment Proclamation No. 299/2002; Addis Ababa, Ethiopia. 2002. Available online: https: //www.ilo.org/dyn/natlex/docs/ELECTRONIC/85156/95183/F804075597/ETH85156.pdf (accessed on 16 May 2021).

22. FDRE Environmental Pollution Control Proclamation No. 300/2002; Addis Ababa, Ethiopia. 2002. Available online: https: //www.vertic.org/media/National\%20Legislation/Ethiopia/ET_Environmental_Pollution_Control.pdf (accessed on 16 April 2021).

23. FDRE Rotterdam Convention Ratification Proc. No. 278/2002; Addis Ababa, Ethiopia. 2002. Available online: https:// ethiopianlaw.weebly.com/uploads/5/5/7/6/5576668/proc_no._278-2002_rotterdam_convention_ratification.pdf (accessed on 25 April 2021).

24. FDRE Basel Convention Ratification Proc. No. 357/2003; Addis Ababa, Ethiopia. 2003. Available online: https://chilot.me/ knowledge-base/basel-protocol-ratification-proclamation-no-357-2003/ (accessed on 8 May 2021).

25. FDRE Solid Waste Management Proclamation No. 513/2007; Addis Ababa, Ethiopia. 2007. Available online: https://chilot.files. wordpress.com/2011/01/proc-no-513-solid-waste-management-proclamation.pdf (accessed on 5 June 2021).

26. FDRE Electrical and Electronic Waste Management and Disposal Reg. No. 425/2018; Addis Ababa, Ethiopia. 2018. Available online: https: / / www.efccc.gov.et/images/PDF/Regulations\%20And\%20Directives /Electronic\%20and\%20Electrical\%20Waste\% 20Management\%20and\%20Disposal\%20Proclamation.pdf (accessed on 19 May 2021).

27. FDRE Hazardous Waste Management and Disposal Control Proc. No. 1090/2018; Addis Ababa, Ethiopia. 2018. Available online: https:/ / chilot.me/wp-content/uploads/2019/08/Proclamation-No.1090-2018-HAZARDOUS-WASTE-MANAGEMENTAND-DISPOSAL-CONTROL-PROCLAMATION.pdf (accessed on 14 June 2021).

28. Kelly, K.; Bjorn, K. Environmental Policy Update 2012: Waste Management for Social and Environmental Benefits in Ethiopian Cities. 2012. Available online: http:/ / web.colby.edu/eastafricaupdate2012/files/2011/12/Chapter-6.-Waste-Management-forSocial-and-Environmental-Benefits-in-Ethiopian-Cities1.pdf (accessed on 7 July 2021).

29. Khan, I.N.G.; Dahalan, W.S.A.W.; Nopiah, Z. Solid Waste Separation at Source among Households for Sustainable Solid Waste Management: The Application of the Solid Waste and Public Cleansing Management Act 2007. Int. J. Asian Soc. Sci. 2018, 8, 201-207. [CrossRef]

30. Jerie, S.; Tevera, D. Solid Waste Management Practices in the Informal Sector of Gweru, Zimbabwe. J. Waste Manag. 2014, 1, 1-7. [CrossRef]

31. Ahsan, A.; Alamgir, M.; El-Sergany, M.M.; Shams, S.; Rowshon, M.K.; Daud, N.N.N. Assessment of Municipal Solid Waste Management System in a Developing Country. Chin. J. Eng. 2014, 1, 1-11. [CrossRef]

32. Sallwey, J.; Hettiarachchi, H.; Hülsmann, S. Challenges and opportunities in municipal solid waste management in Mozambique: A review in the light of nexus thinking. AIMS Environ. Sci. 2017, 4, 621-639. [CrossRef]

33. Orhorhoro, E.K.; Oghoghorie, O. Review on Solid Waste Generation and Management in Sub-Saharan Africa: A Case Study of Nigeria. J. Appl. Sci. Environ. Manag. 2019, 23, 1729. [CrossRef]

34. Kibrekidusan, S. Assessment Of Practices, Challenges And Prospects Of In-House Solid Waste Management In Addis Ababa; The Case Of Yeka Sub City; Addis Ababa University: Addis Ababa, Ethiopia, 2017.

35. World Bank. World Bank What-A-Waste-Report. Urb. Dev. Ser. Knowl. Pap. 2012, 1, 1-116.

36. USAID. Situational Analysis of Urban Sanitation and Waste Management. 2015. Available online: https://www.jsi.com/resource/ situational-analysis-of-urban-sanitation-and-waste-management/ (accessed on 7 July 2021).

37. Molla, A.; Abegaz, T.; Hailu, D. Solid Waste Generation Rate and Characterization Study for 10 Towns in Ethiopia. 2015. Available online: https://www.researchgate.net/publication/327721072_Solid_Waste_Generation_Rate_and_Characterization_study_ for_10_towns_in_Ethiopia (accessed on 7 July 2021).

38. Fereja, W.M.; Chemeda, D.D. Status, characterization, and quantification of municipal solid waste as a measure towards effective solid waste management: The case of Dilla Town, Southern Ethiopia. J. Air Waste Manag. Assoc. 2021, 1, 1-15. [CrossRef] [PubMed]

39. Ferede, Z.M. Assessment Of Domestic Solid Waste Management In Burayu City. 2018. Available online: https://core.ac.uk/ reader / 199939000 (accessed on 7 May 2021).

40. Erasu, D.; Feye, T.; Kiros, A.; Balew, A. Municipal solid waste generation and disposal in Robe town, Ethiopia. J. Air Waste Manag. Assoc. 2018, 68, 1391-1397. [CrossRef]

41. Mohammed, A.; Elias, E. Dometic solid waste management environmental impacts in Addis Ababa city. J. Environ. Waste Manag. 2017, 4, 194-203.

42. Marsie, G.; Hayelom, A.; Birega, G. Existing and Future Msw Generation Nexus Population and Gdp Growth, the Case of Mekele City, Ethiopia. Int. J. Adv. Res. 2017, 5, 1012-1020. [CrossRef]

43. Biruk, A.F. Waste management in the case of Bahir Dar City near Lake Tana shore in Northwestern Ethiopia: A review. Afr. J. Environ. Sci. Technol. 2017, 11,393-412. [CrossRef]

44. Goa, E.; Sota, S.S. Generation rate and physical composition of solid waste in Wolaita Sodo Town, southern Ethiopia. Ethiop. J. Environ. Stud. Manag. 2017, 10, 415. [CrossRef]

45. Mekonnen, D. Assessing Potential and Characterization n of Solid Waste of Jimma Town. Imp. J. Interdiscip. Res. 2017, 3, 1-21. 
46. Assefa, M. Solid Waste Generation Rate and Characterization Study for Laga Tafo Laga Dadi Town, Oromia, Ethiopia. Int. J. Environ. Prot. Plcy 2017, 5, 84. [CrossRef]

47. Abera Kebede, A. Household Solid Waste Generation Rate and Onsite Handling Practices in Debre Berhan Town, Ethiopia. Sci. J. Public Health 2017, 5, 31. [CrossRef]

48. Dimtse, D. Solid waste management in Jijiga, Somali Region: Baseline survey factsheet. RC/HoAREC Consort. 2016, 6, 1-6.

49. Bekele, D.W.; Molla, A.S.M.; Alemayehu, D. Baseline Survey On "Knowledge, Attitude, And Practice (Kap) of Communities And Institutions on Waste Management of Hawassa City And The Lake". 2014. Available online: https: //www.researchgate.net/publication/342053330_BASELINE_SURVEY_ON_KNOWLEDGE_ATTITUDE_AND_PRACTICE_ KAP_OF_COMMUNITIES_AND_INSTITUTIONS_ON_WASTE_MANAGEMENT_OF_HAWASSA_CITY_AND_THE_LAKE (accessed on 7 July 2021).

50. Rai Sharma, H.; Destaw, B.; Negash, T.; Negussie, L.; Endris, Y.; Meserte, G.; Fentaw, B.; Ibrahime, A. Municipal solid waste management in Dessie City. Ethiopia. Manag. Environ. Qual. An Int. J. 2013, 24, 154-164. [CrossRef]

51. Tassie, K.; Endalew, B.; Mulugeta, A. Composition, Generation and Management Method of Municipal Solid Waste in Addis Ababa City, Central Ethiopia: A Review. Asian J. Environ. Ecol. 2019, 9, 1-19. [CrossRef]

52. Kim, J.Y. Solid Waste Management in S. Korea; Seoul National University: Seoul, Korea, 2017.

53. Cheru, M. Solid Waste Management in Addis Ababa: A New Approach to Improving the Waste Management System. 2016. Available online: https:/ / www.theseus.fi/bitstream/handle/10024/121490/Cheru_Meaza.pdf?sequence=1\&isAllowed=y (accessed on 17 April 2021).

54. UNEP. Global Waste Management Outlook. 2015. Available online: https://www.unep.org/resources/report/global--waste-management--outlook (accessed on 17 April 2021).

55. Hawassa City Solid Waste Management Agency. Hawassa City Municipal Solid Waste Management Report; SPNNs: Hawassa, Ethiopia, 2018; pp. 1-14.

56. Wegedie, K.T. Households solid waste generation and management behavior in case of Bahir Dar City, Amhara National Regional State, Ethiopia. Cogent Environ. Sci. 2018, 4, 1-18. [CrossRef]

57. Henry, R.K.; Yongsheng, Z.; Jun, D. Municipal solid waste management challenges in developing countries-Kenyan case study. Waste Manag. 2006, 26, 92-100. [CrossRef]

58. Gedefaw, M. Assessing The Current Status of Solid Waste Management of Gondar Town Ethiopia. Int. J. Sci. Technol. Res. 2015, 4 28-36.

59. Kassahun, T.; Birara, E. Assessment of Solid Waste Management Practices in Bahir Dar City, Ethiopia. Pollution 2018, 4, $251-261$. [CrossRef]

60. AUC Agenda 2063: First Ten-Year Implementation Plan 2014-2023. Available online: https://www.nepad.org/agenda-2063 / publication/agenda-2063-first-ten-year-implementation-plan-2014-2023-0 (accessed on 21 May 2021).

61. Open WASH Urban Sanitation and Solid Waste Management; UK/World Vision Ethiopia/UNICEF; The Open University: Hong Kong, China, 2016.

62. Bjerkli, C.L. Governance on the Ground: A Study of Solid Waste Management in Addis Ababa, Ethiopia. Int. J. Urban Reg. Res. 2013, 34, 1273-1287. [CrossRef]

63. Wilson, D.C.; Velis, C.A.; Rodic, L. Integrated sustainable waste management in developing countries. Proc. Inst. Civ. Eng. Waste Resour. Manag. 2013, 166, 52-68. [CrossRef]

64. Hayal, D.; Hailu, W.; Aramde, F. Assessment of the contemporary Municipal Solid Waste Management in Urban Environment: The case of Addis Ababa Ethiopia. J. Environ. Sci. Technol. 2014, 7, 107-122.

65. Birhanu, Y. Assessment of Solid Waste Management Practices and the Role of Public Participation in Jigjiga Town, Somali Regional State, Ethiopia. Int. J. Environ. Prot. Plcy 2015, 3, 153. [CrossRef]

66. Mohammed, A.A. GIS and Remote Sensing Based Suitable Site Selection for Solid Waste Disposal: A Case Study of Asaita Town, Afar Regional State, Ethiopia; Addis Ababa University: Addis Ababa, Ethiopia, 2016.

67. De Medina-Salas, L.; Castillo-González, E.; Giraldi-Díaz, M.R.; Fernández-Rosales, V.; Manuel, C.; Rodríguez, W. A Successful Case in Waste Management in Developing Countries. J. Pollut. Eff. Ctrl. 2020, 8, 1-5. [CrossRef]

68. Guerrero, L.A.; Maas, G.; Hogland, W. Solid waste management challenges for cities in developing countries. Waste Manag. 2013, 33, 220-232. [CrossRef]

69. Teko, E. Ethiopia Policy Environment Paper. 2018. Available online: http://www.uemi.net/uploads/4/8/9/5/48950199/uemi_ ca_ethiopia--small.pdf (accessed on 13 July 2021).

70. Regassa, N.; Sundaraa, R.D.; Seboka, B.B. Challenges and Opportunities in Municipal Solid Waste Management: The Case of Addis Ababa City, Central Ethiopia. J. Hum. Ecol. 2011, 33, 179-190. [CrossRef]

71. Haylamicheal, I.D.; Desalegne, S.A. A review of legal framework applicable for the management of healthcare waste and current management practices in Ethiopia. Waste Manag. Res. 2012, 30, 607-618. [CrossRef]

72. Gartlehner, G.; Affengruber, L.; Titscher, V.; Noel-Storr, A.; Dooley, G.; Ballarini, N.; König, F. Single-reviewer abstract screening missed 13 percent of relevant studies: A crowd-based, randomized controlled trial. J. Clin. Epidemiol. 2020, 121, 20-28. [CrossRef] [PubMed] 